\title{
Prevalence of Bacillus cereus s.l. in ultra-high temperature chocolate milk from selected milk manufacturers in Malaysia
}

\author{
1,*Ubong, A., ${ }^{5}$ New, C.Y., ${ }^{2}$ Chai, L.C., ${ }^{3}$ Loo, Y.Y., ${ }^{1}$ Nor Khaizura, M.A.R., ${ }^{4}$ Kayali, A.Y. \\ and ${ }^{1}$ Son, R. \\ ${ }^{1}$ Department of Food Science, Faculty of Food Science and Technology, Universiti Putra Malaysia, 43400 \\ UPM Serdang, Selangor, Malaysia. \\ ${ }^{2}$ Institute of Biological Sciences, Faculty of Science, University of Malaya, 50603 Kuala Lumpur, Malaysia. \\ ${ }^{3}$ Department of Food Science, Faculty of Science and Technology, Universiti Kebangsaan Malaysia, 43600 \\ UKM Bangi, Selangor. \\ ${ }^{4}$ Department of Global Humanosphere, Center for Southeast Asian Studies, Kyoto University, Kyoto 606- \\ 8501, Japan. \\ ${ }^{5}$ Go Plus Services Sdn. Bhd., 97A, Jalan BP 6/3, Bandar Bukit Puchong, 47120 Puchong, Selangor Darul \\ Ehsan, Malaysia
}

\begin{abstract}
Article history:
Received: 14 December 2019

Received in revised form: 8 February 2020

Accepted: 10 February 2020 Available Online: 8 March 2020
\end{abstract}

Keywords:

Prevalence,

Bacillus cereus s.l.,

UHT chocolate milk,

MPN-PCR

DOI:

https://doi.org/10.26656/fr.2017.4(4).417

\section{Introduction}

Bacillus cereus is a Gram-positive, rod-shaped and spore-forming bacteria which commonly dwells in soil (Jenson and Moir, 2003; Zhou et al., 2008). Apart from their natural habitat, they are also widely distributed in the environment (Reyes et al., 2007). This bacterium was first defined by Frankland and Frankland (1887) after it was isolated from air in a cowshed (Larsen and Jørgensen, 1997).

Often, this bacterium has been considered as fairly apathogenic; however, $B$. cereus has also been implicated in various infections in man (Kotiranta et al., 2000; McDowell et al., 2019). Apart from that, B. cereus commonly contaminated proteinaceous food such as meat, milk and fish, as well as farinaceous food such as rice, pasta, pastry and noodles (Beecher, 2001; Messelhäusser et al., 2014). Foodborne illness related to $B$. cereus appear as two distinct symptoms; diarrhoeal and emetic. Diarrhoeal symptoms often characterised as diarrhoea and abdominal pain, usually eight to 16 hours after consumption of contaminated food; whereas emetic symptoms can be observed as nausea and vomiting, usually one to five hours (Agata et al., 2002; Caroll et al., 2019). Back in 2013, a massive food poisoning outbreak related to enterotoxigenic $B$. cereus was reported by Schmid et al. (2016). The outbreak was due to consumption of contaminated mashed potato dishes containing B. cereus loads of $10^{5} \mathrm{CFU} / \mathrm{g}$. An outbreak 
involving $B$. cereus was also reported in Italy. The analysis found that basmati rice was contaminated with $B$. cereus and the bacterium was also found in patients' stool (Martinelli et al., 2013). Following that, a large outbreak was reported in 55 nurseries in the United Kingdom after the consumption of food prepared by the same company. The microbiological analysis result showed that $B$. cereus was detected in dried haricot beans (Nicholls et al., 2016).

B. cereus is a common contaminant in the food industry. It was detected in various foods and food products; among food products that are associated with $B$. cereus that have been discovered in other studies are dried milk products (Reyes et al., 2007), RTE cereals (Lee et al., 2009; Lesley et al., 2013), rice (Sarrías et al., 2002; Sandra et al., 2012), minced beef (Samapundo et al., 2011; Bashir et al., 2013; Lesley et al., 2017; Food Safety News, 2018), raw milk and pasteurised milk (de Paula Pacheco-Sanchez and de Massaguer, 2007).

Milk is one of many beverages enjoyed by many people from all walks of life due to its nutritional value, with those available in the market are mostly pasteurised and UHT processed. Processed UHT milk has been deemed safe for consumption due to the efficient elimination of microorganisms during UHT processing. In spite of this, as a common contaminant of raw milk (Christiansson et al., 1999; Bartoszewicz et al., 2008), spores of $B$. cereus can still be detected in the final UHT products (Vyletělová et al., 2002; Tortora et al. 2016b). Therefore, consuming UHT milk could increase the risk of exposure to foodborne pathogens, specifically $B$. cereus (Bahk et al., 2007; Abraha et al., 2017).

In Malaysia, UHT milk is a part of the nutritional program with the aim to reduce malnutrition among school children especially those in rural areas. A total of 7613 schools were supplied with UHT milk for the 1Malaysia Milk Programme (PS1M) to benefit 1.53 million children (Bernama, 2012). The programme came to a halt when there was a local outbreak of $B$. cereus in UHT milk which had affected 191 students (Yusof, 2011). To the author's knowledge, there is insufficient study on the microbiological safety on UHT milk, especially flavoured milk which is more favoured by the children. Therefore, the current study was conducted to investigate the prevalence and contamination level of $B$. cereus s.1 in UHT milk. The outcome of the study will provide an insight into the UHT process of chocolate milk in Malaysia and identify the possible risk factors. On the whole, data collected from this study will help to contribute towards understanding the risk of $B$. cereus infection through the consumption of UHT chocolate milk.

\section{Materials and methods}

\subsection{Sampling}

A total of 214 packages of UHT milk were collected from two manufacturers (A and B - factory names were not to be disclosed due to confidential purposes), in Malaysia were analysed in this study. The samples were transported and immediately analysed upon arrival to the laboratory.

\subsection{Most probable number-polymerase chain reaction $(M P N-P C R)$}

Enumeration was performed according to the method described by Lee et al. (2009), and Tallent et al. (2012) with modifications according to Cappuccino et al. (2014) and Sandra et al. (2012). Homogenized samples in tryptic soy broth were diluted to 100 -fold and 1000 -fold for MPN three tubes test and incubated at $37^{\circ} \mathrm{C}$ for 48 hrs. Turbid MPN tubes were subjected to DNA extraction via boil cell method (Tunung et al. 2010). Briefly, one $\mathrm{mL}$ of culture was centrifuged at $13,400 \times \mathrm{g}$ for 1 min and the pellet was resuspended in $500 \mu \mathrm{L} \mathrm{TE}$ (Tris-EDTA) buffer. The suspension was boiled for 10 min and immediately cooled at $-20^{\circ} \mathrm{C}$ for 10 mins. The suspension was centrifuged again for $1 \mathrm{~min}$ at 13, $400 \times$ $g$. The boiled cell lysate was used as template for PCR assay.

Bacillus spp. and B. cereus s.l. was detected by PCR assay performed in a $25 \mu \mathrm{L}$ reaction mixture containing $5 \mu \mathrm{L}$ of $5 \times$ Green GoTaq ${ }^{\circledR}$ Flexi Buffer, $1.5 \mathrm{mM}$ of $\mathrm{MgCl}_{2}, 0.08 \mathrm{mM}$ of dNTP mix, $0.2 \mu \mathrm{M}$ of each primer, 1 $\mathrm{U} / \mu \mathrm{L} \mathrm{Taq}$ polymerase (Promega, USA), and $2.5 \mu \mathrm{L}$ of DNA template. Amplification was performed at $94^{\circ} \mathrm{C}(5$ mins) for pre-denaturation, denaturation at $94^{\circ} \mathrm{C}(1 \mathrm{~min})$, annealing at $55^{\circ} \mathrm{C}(1 \mathrm{~min})$, extension at $72^{\circ} \mathrm{C}(1 \mathrm{~min})$ and final extension at $72^{\circ} \mathrm{C}$ (4 mins). The products were electrophoresed on $1 \%$ agarose gel with $1 \times$ TBE (TrisBorate-EDTA) buffer at $100 \mathrm{~V}$ for 28 mins. Table 1 shows the list of primer sequences used in this study.

Table 1. Primer sequences used in this study.

\begin{tabular}{clccc}
\hline Primer & \multicolumn{1}{c}{ Sequence } & Annealing Temperature & Reference & Amplicon Size (bp) \\
\hline $\begin{array}{c}\text { Bacillus } \\
\text { spp. }\end{array}$ & $\begin{array}{l}\text { F: 5'-TCACCAAGGCAACGATGCG-3' } \\
\text { R: 5'-CGTATTCACCGCGGCATG-3' }\end{array}$ & $55^{\circ} \mathrm{C}, 1 \mathrm{~min}$ & Wu et al. (2005) & 1114 \\
\hline \multirow{2}{*}{ B. cereus } & F: 5'-GAGTTAGAGAACGGTATTTATGCTGC-3' \\
& R: 5'-CTACTGCCGCTCCATGAATCC-3' & $55^{\circ} \mathrm{C}, 1 \mathrm{~min}$ & $\begin{array}{c}\text { Schraft and } \\
\text { Griffiths (1995) }\end{array}$ & 411 \\
\hline
\end{tabular}




\subsection{Isolation of B. cereus isolates}

Turbid MPN tubes were streaked on Mannitol-YolkPolymyxin agar and incubated at $37^{\circ} \mathrm{C}$ for 18 to $24 \mathrm{hrs}$. Suspected single pink to purple colonies which were surrounded by a ring of dense precipitation of $B$. cereus was picked for further confirmation by PCR.

\section{Results and discussion}

In this study, Bacillus spp. and B. cereus s.l. were detected in $31.11 \%(67 / 214)$ and $24.30 \%(52 / 214)$ of the UHT chocolate milk samples, respectively, with MPN distribution ranging from less than 3 to more than 1100 $\mathrm{MPN} / \mathrm{mL}$. Majority of the samples were detected with concentration less than $3 \mathrm{MPN} / \mathrm{mL} ; 68.69 \%$ and $75.70 \%$ for Bacillus spp. and B. cereus s.l. respectively. For concentration range of 3 to $9.4,11$ to 93 , and 120 to $1100 \mathrm{MPN} / \mathrm{mL}$ for Bacillus spp., the percentage was $19.61 \%, 5.61 \%$ and $0.47 \%$ respectively; for $B$. cereus s.l., the percentage were $14.49 \%, 3.74 \%$ and $1.87 \%$ respectively. Bacillus spp. and $B$. cereus s.l. with concentration more than $1100 \mathrm{MPN} / \mathrm{mL}$ account for $6.07 \%$ and $4.21 \%$ of the samples respectively (Figure 1). Figures 2 and 3 show representative positive samples detected with Bacillus spp. and B. cereus s.l.

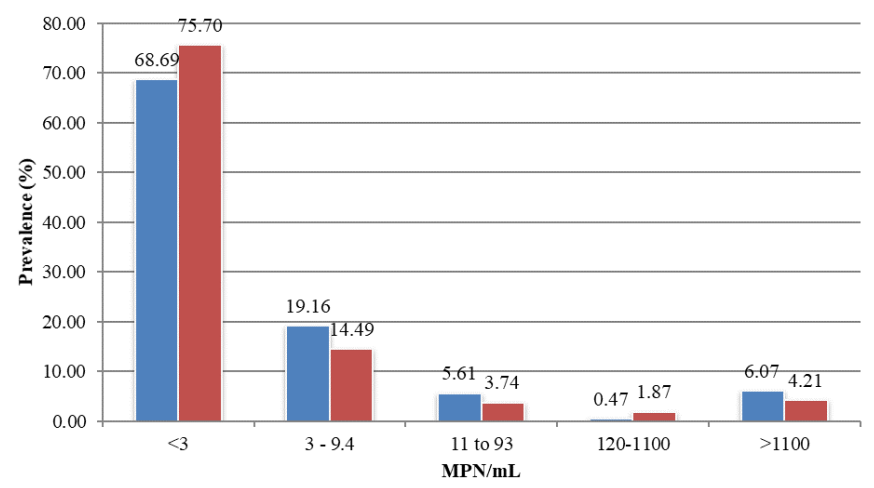

Figure 1. Percentage of contamination level of Bacillus spp. (indicated in blue bars) and B. cereus (indicated in red bars) in UHT chocolate milk.

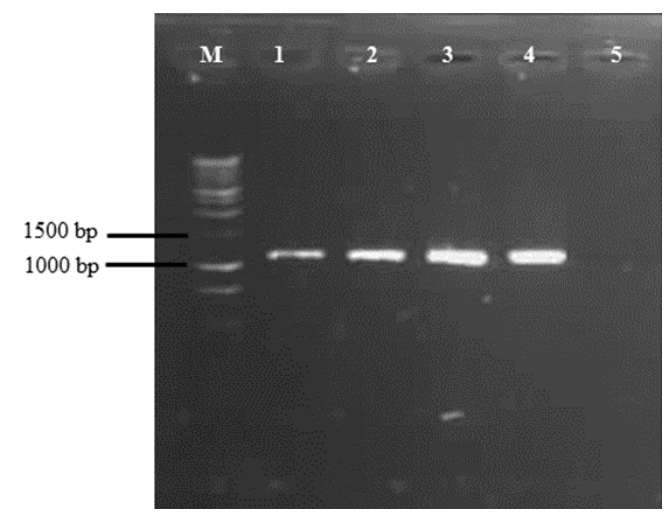

Figure 2. Representative amplification of 16S rRNA gene for the detection of Bacillus spp. (1114 bp). Lane M: $1 \mathrm{~kb}$ DNA ladder (Promega, USA); lane 1 to 3 : representative positive samples at $1114 \mathrm{bp}$; lane 4: positive control (B. cereus ATCC 33019); lane 5: non-Bacillus spp. sample.

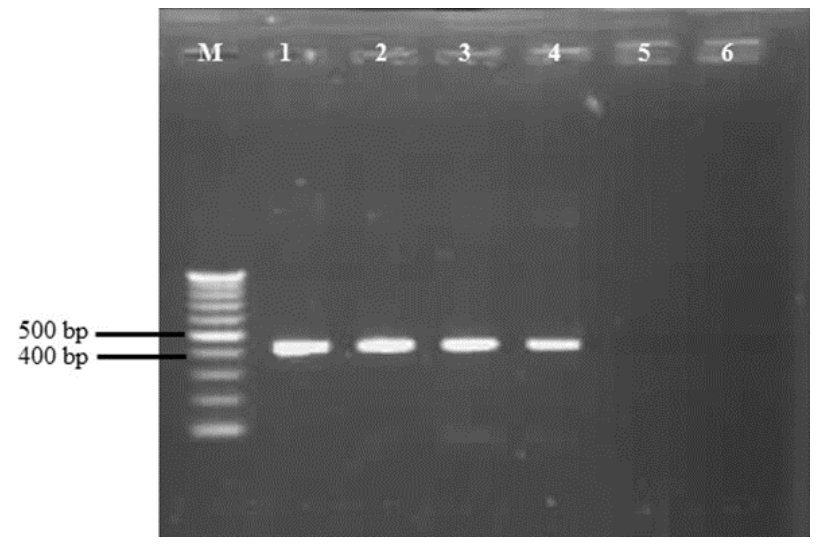

Figure 3. Representative amplification of cereolysin $\mathrm{AB}$ gene for the detection of $B$. cereus s.l. (411 bp). Lane M: $100 \mathrm{bp}$ DNA ladder (Promega, USA); lane 1 to lane 3: representative positive samples at $411 \mathrm{bp}$; lane 4: positive control (B. cereus ATCC 33019); lane 5 and lane 6: non-B. cereus sample.

The median MPN distribution samples collected in this study is less than $3 \mathrm{MPN} / \mathrm{mL}$, in which it accounts for the majority of the MPN distribution. Thence, it is suggested that majority of the chocolate milk samples were safe for consumption as B. cereus s.l. was not detected in any of the samples. However, it should be kept in mind that when samples were 'not detected' with $B$. cereus s.l., it does not mean that the samples were free from the said bacterium. The number of B. cereus s.l. was below detected limit, therefore, they were not detected by MPN-PCR assay. Nevertheless, samples with less than $3 \mathrm{MPN} / \mathrm{mL}$ could also pose a threat to consumers.

The results of the study were in agreement with Lesley et al. (2017) who reported $30 \%$ of UHT milk sampled in retail markets in Sarawak, East Malaysia. Vidal-Martins et al. (2005) detected B. cereus in $11.8 \%$ of the 110 samples of UHT milk in their research, wherein the detection is lower compared to the present study. A slightly higher detection was described by Rezende-Lago et al. (2007); 58.3\% of 120 samples consisting of raw milk, milk powder, UHT milk and pasteurised milk were contaminated with $B$. cereus, but detection was lower in UHT milk (13.3\%). The presence of $B$. cereus in UHT milk was also reported in previous studies (Bartoszewicz et al., 2008; Ghellai and Moussaboudjemaa, 2013) which are parallel with the present study. Prevalence of $B$. cereus s.l. in this study is higher compared to the prevalence of $B$. cereus in UHT milk mentioned previously in other studies. It can be suggested that it might be due to the high microbial load from raw materials which can lead to the high number of successive spores (Vyletělová et al., 2002; Amor et al., 2018).

In another related study, Schlegelova et al. (2003) reported that $31.0 \%$ of dairy foodstuff samples were contaminated with $B$. cereus, showing similar prevalence 
to the present study. Another related research stated that B. cereus was found in $45.9 \%$ of dried milk products (Reyes et al., 2007) and analysis by a local study indicated that $78 \%$ of 111 RTE cereals were detected with $B$. cereus s.l., showing a higher detection compared to present study (Lee at al., 2009). Apart from that, more information on $B$. cereus isolation from various milk and milk products has also been described from the following researches; fresh milk as well as heat-treated milk such as pasteurised milk and UHT milk (Vyletělová et al., 2002; Salustino et al., 2009; Hassan et al., 2010; Fallah et al., 2011; Montanhini et al., 2013; Kumari and Sarkar, 2016).

UHT processing for milk is a process of continuous heating at temperatures higher than $130^{\circ} \mathrm{C}$ (generally at $140^{\circ} \mathrm{C}$ to $150^{\circ} \mathrm{C}$ ) for a holding time of a few seconds (generally 2 to $10 \mathrm{~s}$ ). Following that, the milk is aseptically packaged to produce a 'commercially sterile' product. Hence, under these conditions, microorganisms that are capable of growing under normal condition of product storage are eventually destroyed (Datta et al., 2002; Kjaerulff, 2013). In food industries, UHT processing is the favoured way of sterilising chocolate flavoured milk as it will enhance the flavour of the chocolate without causing bitter aftertaste. What is more, it provides an overall smoothness and favourable taste and at the same time, it extends its shelf-life (Bixler et al., 2001; Tiwari and Asgar; 2017). Although the chocolate milk has initially gone through the sterilisation process before being distributed to local retail markets, there were many possible aspects to be considered for $B$. cereus s.l. recontamination on the final products.

Doyle et al. (2016) described that the possible reason for contamination of milk occurs during the outdoor grazing period. It was suggested that soil was the main source of contamination for milk by means of cow's teat that came in contact with soil (Christiansson et al., 1999; Doyle et al., 2016). On that account, the spores eventually came in contact with raw milk during the cows' milking process. Spores in manure may also contribute to some degree of spore in milk, given with high spore content in the soil. In the processing environment, B. cereus spores in raw milk will continue to persist after pasteurisation and later on will continue to colonise pipes, storage tanks and filling machines (Jenson and Moir, 2003; Gopal et al., 2015). However, most milk manufacturing plants in Malaysia used reconstituted milk for economic reasons. The spores present in raw milk could remain even after the milk was transformed into a powdered form may suggest highly thermo liable spores which are greatly influenced by the genetic group (Sandra et al., 2012; Lesley et al., 2013).
The spores transfer was suspected to be likely initiated from the raw materials. Commercially produced chocolate milk is usually prepared by mixing raw ingredients such as raw milk or milk powder with cocoa powder, sugar, thickening agent, food stabiliser and preservatives. Selected raw ingredients collected from the factories were subjected to examination for the presence of $B$. cereus s.l. From 32 samples of raw ingredients, $22(68.6 \%)$ samples were detected with $B$. cereus s.l. with MPN distribution ranges from less than 3 $\mathrm{MPN} / \mathrm{mL}$ to more than $1100 \mathrm{MPN} / \mathrm{mL}$. This indicates that most of the raw materials contained $B$. cereus spores. The spores which might be present in these raw ingredients may successfully be transferred during the milk processing course (Vyletělová et al., 2002; Amor et al., 2018) and surviving the UHT process, if the spores are incompletely inactivated. Generally, $B$. cereus utilises glucose as its main carbon source (Tallent et al., 2012). Apart from that, it is also capable of fermenting sucrose (Aryal, 2019). The high content of sugar in UHT chocolate milk (7.2 g of sucrose per $200 \mathrm{~mL}$ of UHT chocolate milk pack) could support the spore germination and growth. In addition, the use of different food ingredients, especially exotic and imported, creates new niches and risk of introducing new unknown heatstable spore-formers into the production process (Witthuhn et al., 2011). According to a study conducted by Witthuhn et al. (2011) on the thermal stability of spores, it was concluded that cocoa powder was shown to contain highly heat-resistant spores.

The initial designs of UHT processes focused on the inactivation of thermophilic bacterial spores such as spores of Geobacillus stearothermophilus due to their survivability in UHT heating (Witthuhn et al., 2011). It was reported that the spores are activated at $121^{\circ} \mathrm{C}$ and to inactivate the spores requires temperatures well above $121^{\circ} \mathrm{C}$ (Russell, 1982; Huesca-Espitia et al., 2016). However, the introduction of extremely heat-resistant mesophilic spore-former Bacillus sporothermodurans (IDF, 2000) had impacted the UHT industry, making a fine line in achieving the inactivation required with the milk quality. In reality, higher temperature will ensure complete inactivation of the spores. Despite the proposed inactivation kinetics, severe chemical changes will be observed, for example, browning, loss vitamins, fouling and gelation, which degrades the quality of milk. What more when the distribution of unknown very heat-stable spores or the evolution of spore-formers such as $B$. cereus, a mesophilic and foodborne pathogen into producing heat-stable spores.

During the production of UHT milk, there is a possibility for the activation of the spores which led to germination. Levinson and Hyatt (1970) reported that the 
activation of $B$. cereus spores is within $62^{\circ} \mathrm{C}$ to $78^{\circ} \mathrm{C}$ and maximal rate of spore germination was at $64^{\circ} \mathrm{C}$ to $68^{\circ} \mathrm{C}$. The activation temperature is within the range of the holding temperature of most UHT processes which brings the possibility that the spore's germination in a longer indirect heating system, posing a hazard to the design of safe processes.

Apart from their ability to survive harsh environment via endospores, B. cereus s.l. is also known to form biofilm which is a huge concern for the food industry. In fact, $B$. cereus' ability to form biofilm has been extensively reported in many researches, colonising surfaces such as stainless steel, glass, plastic, leafy vegetable and polystyrene (Ryu and Beuchat, 2005; Hsueh et al., 2006; Houry et al., 2009; Elhairy, 2011; Majed et al., 2016; Hussain et al., 2018). It is possible that during processing, B. cereus cells anchor to the surfaces of pipe, storage tanks and filling machines, eventually colonising them (Jenson and Moir, 2003; Gopal et al., 2015; Majed et al., 2016). They will ultimately produce matrix and form stronger biomasses, with a matrix forming a hydrophobic envelope surrounding the biofilm. The extracellular matrix is primarily comprised of polysaccharides, such as cellulose, proteins or exogenous DNA. The matrix can fix to hard surfaces such as food industry equipment, transport, dispensing and storage surfaces and soil; or to biological structures such as vegetables, meat, bones and fruits. The embedded cells are protected against toxic compounds, due to the matrix's structural role which responsible for durability and persistency of biofilm. Biofilm formation provides many advantages to microbial cells, especially in the food industry setting. For example, physical resistance against desiccation, mechanical resistance against liquid streams in pipelines, and chemical protection against chemicals, antimicrobials and disinfectants used in the food industry (Flemming et al., 2016; Galié et al., 2018). It can contain spores as well as vegetative cells with spores and result in recontamination during the detachment of these biofilms (Faille et al., 2014).

Thenceforth, biofilms are very difficult to eliminate as they exhibit resistant to high temperature and disinfection processes compared to bacteria in the freeliving environment. In sync with spores, it gives $B$. cereus high resistance to numerous stress as well as high adhesive capacity on various substrates, which includes stainless steel, a common material used in food processing. Moreover, sporulation occurs at a very high level in biofilms, which makes them difficult to eliminate. It is of great concern when biofilms start to form in areas which are difficult to clean, for example, crevices, valve, gaskets and dead ends (Donlan, 2002;
Majed et al., 2016).

Contamination of UHT chocolate milk could also take place during the cooling process as milk was passed through the cooling chamber, a potential area for biofilm colonisation. Contamination also causes by the reintroduction of spores during the filling process; when chocolate milk was dispensed into smaller packs. These spores might come from biofilms that have colonised dispenser nozzles and eventually released into previously sterilised chocolate milk. Another possible route of contamination was the chocolate milk could also expose to airborne $B$. cereus spores during the filling process (Actor, 2012). Hence, when optimum temperature is reached for $B$. cereus growth, the spores will germinate and return to their vegetative state (Tortora et al., 2016; Majed et al., 2016).

It is critical to take note that low numbers of $B$. cereus cells could also cause illness. Lee et al. (2009) mentioned in their study on the incident of a low infective dose of $B$. cereus that caused serious food poisoning outbreak in Norway; with a number as low as $10^{3}$ to $10^{4}$ cells $/ \mathrm{mL}$, food industries should be a concern (Granum, 1994). A total of $4.21 \%$ of UHT milk samples from this study contained more than $1100 \mathrm{MPN} / \mathrm{mL}$ of $B$. cereus. Considering the fact that $10^{3}$ cells $/ \mathrm{mL}$ could lead to infection, this UHT milk could pose risk to consumers. In addition to that, milk is a good medium to support the germination of $B$. cereus due to its nutritious content (Ray and Bhunia, 2008). As such milk is consumed more by infant and children for its nutrients and who bear the highest foodborne disease burden (Kirk et al., 2015), it is, therefore, necessary to monitor the microbiological safety of milk.

\section{Conclusion}

Detection of $B$. cereus s.l. and other foodborne pathogens is vital for the safety of food products. Findings from this study highlighted the possibility of UHT chocolate milk as a potential source of $B$. cereus s.l. infection. In this manner, it is of significant important to revise, monitor and improve UHT sterilization and packaging processes in order to reduce infection risk. From food safety point of view, thorough and continuous monitoring of $B$. cereus s.l. during UHT milk production process is important in order to address B. cereus s.l. infection issue as UHT milk is a potential medium to acquire its infection. Furthermore, it is also imperative to supervise and maintain the hygienic level to minimize initial microbial load and contamination, beginning from production to table in order to safeguard consumers along with public health. 


\section{Conflict of Interest}

The authors declare no conflict of interest.

\section{Acknowledgment}

This research was supported by the National Biotechnology Division, Ministry of Science, Technology Malaysia under the grant (02-01-04SF1526) and Fundamental Research Grant Scheme (FRGS) of Ministry of Higher Education (MOHE), Malaysia (01-01-18-2015FR) in parts with AMED under Grant No.: JP15km0908001.

The authors acknowledged the late Professor Dr Mitsuaki Nishibuchi from the Department of Humanosphere, Center for Southeast Asian Studies, Kyoto University, Kyoto, Japan, for his generous support in this research.

\section{References}

Abraha, A., Bikila, T., Alemu, S. and Muktar, Y. (2017). Bacillus cereus isolation and load from raw cow milk sold in Markets of Haramaya District, eastern Ethiopia. International Journal of Food Contamination, 4, 1-6. https://doi.org/10.1186/ s40550-017-0060-Z

Actor, J.K. (Ed.) (2012). Clinical Bacteriology. In Elsevier's Integrated Review Immunology and Microbiology. $2^{\text {nd }}$ ed., p. 105-120. USA: Elsevier https://doi.org/10.1016/B978-0-323-07447-6.000120

Agata, N., Ohta, M. and Yokoyama, K. (2002). Production of Bacillus cereus emetic toxin (cereulide) in various foods. International Journal of Food Microbiology, 73(1), 23-27. https:// doi.org/10.1016/S0168-1605(01)00692-4

Amor, M.G.B., Siala, M., Zayani, M., Grosset, N., Smaoui, S., Messadi-Akrout, F., Baron, F., Jan, S., Gautier, M. and Gdoura, R. (2018). Isolation, Identification, Prevalence, and Genetic Diversity of Bacillus cereus Group Bacteria from Different Foodstuffs in Tunisia. Frontiers in Microbiology, 9 (447), 1-12. https://doi.org/10.3389/ fmicb.2018.00447

Aryal, S. (2019). Biochemical Test and Identification of Bacillus cereus. Retreived on December 13, 2019 from Microbiology Info Website: https:// microbiologyinfo.com/biochemical-testidentification-bacillus-cereus/.

Bahk, G.J., Todd, E.C.D., Hong, C.H., Oh, D.G. and Ha, S.D. (2007). Exposure assessment for Bacillus cereus in ready-to-eat Kimbab selling at stores. Food Control, 18(6), 682-688. https://doi.org/10.1016/ j.foodcont.2006.02.017

Bartoszewicz, M., Hansen, B.M. and Swiecicka, I. (2008). The members of Bacillus cereus groups are commonly present contaminants of fresh and heattreated milk. Food Microbiology, 25(4), 588-596. https://doi.org/10.1016/j.fm.2008.02.001

Bashir, M., Malik, M.A., Javaid, M., Badroo, G.A., Bhat, M.A. and Singh, M. (2017). Prevalence and Characterization of Bacillus cereus in Meat and Meat Products in and around Jammu Region of Jammu and Kashmir, India. International Journal of Current Microbiology and Applied Sciences, 6(12), 1094-1106. ijcmas.2017.612.124

https://doi.org/10.20546/

Beecher, D.J. (2002). The Bacillus cereus Group. In Sussman, M. (Ed.) Molecular Medical Microbiology. Vol. 2, p. 1161-1190. USA: Academic Press. https:// doi.org/10.1016/B978-012677530-3/50276-2

Bernama. (2012). Borneo Post Online. Leftover milk may cause gastrointestinal disorder. Retrieved from February 25, 2019 from Borneo Post Online website: https://www.theborneopost.com/2012/10/26/leftover -milk-may-cause-gastrointestinal-disorder/.

Bixler, H.J., Johndro, K. and Falshaw, R. (2001). Kappa2 carrageenan: structure and performance of commercial extracts II. Performance in two simulated dairy applications. Food Hydrocolloids, 15 (4-6), 619-630. https://doi.org/10.1016/S0268-005X (01)00047-9

Cappuccino, J.G. and Sherman, N. (2014). Microbiology of Water. In Berriman, L., Beuagureau, M., Earl, W. and Novak, D. (Eds.). Microbiology: A Laboratory Manual. $10^{\text {th }}$ ed., p. 327-342. California: Pearson: Benjamin Cummings.

Caroll, L.M., Wiedmann, M., Mukherjee, M., Nicholas, D.C., Mingle, L.A., Dumas, N.B., Cole, J. and Kovac, J. (2019). Characterization of Emetic and Diarrheal Bacillus cereus Strains From a 2016 Foodborne Outbreak Using Whole-Genome Sequencing: Addressing the Microbiological, Epidemiological, and Bioinformatic Challenges. Frontiers in Microbiology, 10, 1-20. https:// doi.org/10.3389/fmicb.2019.00144

Christiansson, A., Bertilsson, J. and Svensson, B. (1999). Bacillus cereus spores in raw milk: Factors affecting the contamination of milk during grazing period. Journal of Dairy Science, 82, 305-314. https:// doi.org/10.3168/jds.S0022-0302(99)75237-9

Datta, N., Elliott, A.J., Perkins, M.L. and Deeth, H.C. (2002). Ultra-high-temperature (UHT) treatment of milk: Comparison of direct and indirect modes of heating. Australian Journal of Dairy 
Technology, 57(3), 211-227.

de Paula Pacheco-Sanchez, C. and de Massaguer P.R. (2007). Bacillus Cereus in Brazilian Ultra High Temperature Milk. Scientia Agricola, 64(2), 152161. https://doi.org/10.1590/S010390162007000200008

Donlan, R.M. (2002). Biofilms: Microbial life on surface. Emerging Infectious Disease, 8(9), 881-890. https://doi.org/10.3201/eid0809.020063

Doyle, C.J., Gleeson, D., O'Toole, W. and Cotter, P.D. (2016). Impacts of Seasonal Housing and Teat Preparation on Raw Milk Microbiota: a HighThroughput Sequencing Study. Applied and Environmental Microbiology, 83(2), 1-12. https:// doi.org/10.1128/AEM.02694-16

Elhairy, H.M. (2011). Attachment strength and biofilm forming ability of Bacillus cereus on green-leafy vegetables: Cabbage and lettuce. Food Microbiology, 28(7), 1266-1274. https:// doi.org/10.1016/j.fm.2011.05.004

Faille, C., Bénézech, T., Midelet-Bourdin, G., Lequette, Y., Clarisse, M., Ronse, G., Ronse, A. and Slomianny, C. (2014). Sporulation of Bacillus spp. within biofilms: a potential source of contamination in food processing environments. Food Microbiology, 40, 64-74. https://doi.org/10.1016/ j.fm.2013.12.004

Fallah, S., Chamani, M., Aminafshar, M. and Ezzatpanah, H. (2011). Genomic study of the cereolysin A and B genes in Bacillus cereus isolated from raw and pasteurised milk. African Journal of Biotechnology, 10, 439-441.

Flemming, H.C., Wingender, J., Szewzyk, U., Steinberg, P., Rice, S.A. and Kjelleberg, S. (2016). Biofilms: an emergent form of bacterial life. Nature Review Microbiology, 14, 563-575. https://doi.org/10.1038/ nrmicro.2016.94

Food Safety News. (2018). Study looks at rate of Bacillus cereus in infant formula in China. Retrieved March 5, 2018 from Food Safety News webstie: https://www.foodsafetynews.com/2018/11/studylooks-at-rate-of Bacillus-cereus-in-infant-formula-inchina/.

Frankland, G.C. and Frankland, P.F. (1887). Studies on some new micro-organisms obtained from air. Philosophical Training of the Royal Society B, 178, 257-287. https://doi.org/10.1098/rstb.1887.0011

Galié, S.,García-Gutiérrez, C., Miguélez, E.M., Villar, C.J. and Lombó, F. (2018). Biofilms in the Food Industry: Health Aspects and Control Methods. Frontiers in Microbiology, 9(989), 1-18. https:// doi.org/10.3389/fmicb.2018.00898
Ghellai, L. and Moussaboudjemaa, B. (2013). Aerobic spore-forming bacteria in the Ultra High Temperature milk produced in the North West of Algeria. Journal of Agricultural Science and Technology A, 3, 697-702.

Gopal, N., Hill, C., Ross, P.R., Beresford, T.P., Fenelon, M.A. and Cotter, P.D. (2015). The Prevalence and Control of Bacillus and Related Spore-Forming Bacteria in the Dairy Industry. Frontiers in Microbiology, 6(1418), 1-18. https:// doi.org/10.3389/fmicb.2015.01418

Granum, P.E. (1994). Bacillus cereus and its toxin. Journal of Applied Bacteriology, 76(S23), 615-665. https://doi.org/10.1111/j.1365-2672.1994.tb04358.x

Hassan, G.M., Al-Ashmawy, M.A.M., Meshref, A.M.S. and Afify, S.I. (2010). Studies on enterotoxigenic Bacillus cereus in raw milk and some dairy products. Journal of Food Safety, 30(3), 569-583. https:// doi.org/10.1111/j.1745-4565.2010.00226.x

Huesca-Espitia, L.C., Suvira, M., Rosenbeck, K., Korza, G., Setlow, B., Li, W., Wang, S., Li, Y.Q. and Setlow, P. (2016). Effects of steam autoclave treatment on Geobacillus stearothermophilus spores. Journal of Applied Microbiology, 121(5), 13001311. https://doi.org/10.1111/jam.13257

Houry, A., Briandet, R., Aymerich, S. and Gohar, M. (2009). Involvement of motility and flagella in Bacillus cereus biofilm formation. Microbiology, 156(2010), 1009-1018. https://doi.org/10.1099/ mic. $0.034827-0$

Hsueh, Y.H., Somers, E.B., Lereclus, D. and Wong, A.C.L. (2006). Biofilm Formation by Bacillus cereus Is Influenced by PlcR, a Pleiotropic Regulator. Applied and Environmental Microbiology, 70(7), 5089-5092. https://doi.org/10.1128/AEM.00573-06

Hussain, M.S., Kwon, M. and Oh, D.H. (2018). Impact of manganese and heme on biofilm formation of Bacillus cereus food isolates. PLOS One, 13(7), e0200958. https://doi.org/10.1371/ journal.pone. 0200958

International Dairy Federation (IDF). (2000). Bacillus sporothermodurans - a Bacillus forming highly heat -resistant spores. Bulletin of the International Dairy Federation, 357, 3-27.

Jenson, I. and Moir, C.J. (2003). Bacillus cereus and other Bacillus species. In Hocking, A.D. (Ed.) Foodborne Microorganisms of Public Health Significance. $6^{\text {th }}$ ed., p. 445-478. Australia: Australian Institute of Food Science and Technology Incorporated NSW Branch, Food Microbiology Group.

Kirk, M.D., Pires, S.M., Black, R.E., Caipo, M., Crump, 
J.A., Devleesshauwer, B., Dopfer, D., Fazil, A., Fischer-Walker, C.L., Hald, T., Hall, A.J., Keddy, K.H., Lake, R.J., Lanata, C.F., Togerson, P.R., Havelaar, A.H. and Angulo, F.J. (2015). World Health Organisation Estimates of the Global and Regional Disease Burden of 22 Foodborne Bacterial, Protozoal, and Viral Diseases, 2010: A Data Synthesis. PLoS Medicine, 12(12), 1-21. https:// doi.org/10.1371/journal.pmed.1001940

Kjaerulff, G. (2013). How Can Steam Infusion UHT Eliminate Microorganisms? Retrieved on August 12, 2018 from Food Quality and Safety Website: https:// www.foodqualityandsafety.com/article/how-cansteam-infusion-uht-eliminate-microorganisms/.

Kotiranta, A., Lounatmaa, K. and Haapasalo, M. (2000). Epidemiology and pathogenesis of Bacillus cereus infections. Microbes and Infection, 2(2), 189-198. https://doi.org/10.1016/S1286-4579(00)00269-0

Kumari, S. and Sarkar, P.K. (2016). Bacillus cereus hazard and control in industrial dairy processing environment. Food Control, 69, 20-29. https:// doi.org/10.1016/j.foodcont.2016.04.012

Larsen, H.D. and Jørgensen, K. (1997). The occurrence of Bacillus cereus in Danish pasteurised milk. International Journal of Food Microbiology, 34(2), 179-186. https://doi.org/10.1016/S0168-1605(96) 01182-8

Lee, H.Y., Chai, L.C., Tang, S.Y., Jinap, S., Ghazali, F.M., Nakaguchi, Y., Mitsuaki, M. and Son, R. (2009). Application of MPN-PCR in biosafety of Bacillus cereus s.l for ready-to-eat cereals. Food Control, 20(11), 1068-1071. https://doi.org/10.1016/ j.foodcont.2009.01.009

Lesley, M.B., Ernie, S.R., Kasing, A. and Son, R. (2017). Detection of Bacillus cereus in formula milk and ultra-high temperature (UHT) treated milk products. International Food Research Journal, 24 (3), 985-989.

Lesley, M.B., Velnetti, L., Yousr, A.N., Kasing. A. and Samuel, L. (2013). Presence of Bacillus cereus s.l. from ready-to-eat cereals (RTE) products in Sarawak. International Food Research Journal, 20 (2), 1031-1034.

Levinson, H.S. and Hyatt, M.T. (1970). Effects of Temperature on Activation, Germination and Outgrowth of Bacillus megaterium Spores. Journal of Bacteriology, 101, 58-64. https://doi.org/10.1128/ JB.101.1.58-64.1970

Majed, R., Faille, C., Kallasy, M. and Gohar, M. (2016). Bacillus cereus Biofilms - Same, Only Different. Frontiers in Microbiology, 7(1054), 1-16. https:// doi.org/10.3389/fmicb.2016.01054
Martinelli, D., Fortunato, F., Silvio Tafuri, S., Cozza, V., Chironna, M., Germinario, C., Pedalino, B. and Prato, R. (2013). Lessons learnt from a birthday party: a Bacillus cereus outbreak, Bari, Italy, January 2012. Ann Ist Super Sanità, 49(4), 391-394.

McDowell, R.H. (2019). Bacillus cereus. Retrieved on August 10, 2019 from NCBI website: https:// www.ncbi.nlm.nih.gov/books/NBK459121/.

Messelhäusser, U., Frenzel, E., Blöchinger, C., Zucker, R., Kämpf, P. and Ehling-Schulz, M. (2014). Emetic Bacillus cereus Are More Volatile Than Thought: Recent Foodborne Outbreaks and Prevalence Studies in Bavaria (2007-2013). BioMed Research International, 2014, 1-9. https:// doi.org/10.1155/2014/465603

Montanhini, M.T.M., Montanhini, R.N., Pinto, J.P.N. and Bersot, L.S. (2013). Effect of temperature on the lipolytic and proteolytic activity of Bacillus cereus isolated from dairy products. International Food Research Journal, 20, 1417-1420. https:// doi.org/10.4025/actascitechnol.v35i1.13752

Nicholls, M., Purcell, B., Willis, C., Amar, C.F., Kanagarajah, S., Chamberlain, D., Wooldridge, D., Morgan, J., McLauchlin, J., Grant, K.A., HarveyVince, L., Padfield, M., Mearkle, R. and Chow, J.Y. (2016). Investigation of an outbreak of vomiting in nurseries in South East England, May 2012. Epidemiology and Infection, 144(3), 582-590. https://doi.org/10.1017/S0950268815001491

Ray, B. and Bhunia, R. (2008). Normal Microbiology Quality of Foods and Its Significance. In Fundamental Food Microbiology. $4^{\text {th }}$ ed., p. 35-41. Florida: CRC Press Taylor and Francis Group.

Reyes, J.E., Bastías, J.M., Gutiérrez, M.R. and Rodríguez, M.O. (2007). Prevalence of Bacillus cereus in dried milk products used by Chilean School Feeding Program. Food Microbiology, 24(1), 1-6. https://doi.org/10.1016/j.fm.2006.04.004

Rezende-Lago, N.C.M., Rossi, O.D., Vidal-Martins, A.M.C. and Amaral, L.A. (2007). Occurrence of Bacillus cereus in whole milk and enterotoxigenic potential of the isolated strains. Arquivo Brasileiro De Medicina Veterinaria E Zootecnia, 59(6), 15631569. https://doi.org/10.1590/S010209352007000600032

Russell, A.D. (1982). The Destruction of Bacterial Spores. New York, USA: Academic Press.

Ryu, J.H. and Beuchat, L.R. (2005). Biofilm Formation and Sporulation by Bacillus cereus on a Stainless Steel Surface and Subsequent Resistance of Vegetative Cells and Spores to Chlorine, Chlorine Dioxide, and a Peroxyacetic Acid-Based Sanitiser. 
Journal of Food Protection, 68(12), 2614-2622. https://doi.org/10.4315/0362-028X-68.12.2614

Salustino, V.V., Andrade, N.J., Soares, N.F.F., Lima, J.C., Bernades, P.C., Luiz, L.M.P. and Fernandes, P.E. (2009). Contamination of milk with Bacillus cereus by post-pasteurisation surface exposure as evaluated by automated ribotyping. Food Control, 20(4), 439-442. https://doi.org/10.1016/ j.foodcont.2008.07.004

Samapundo, S., Heyndrickx, M., Xhaferi, R. and Devlieghere. (2011). Incidence, diversity and toxin gene characteristics of Bacillus cereus group strains isolated from food products marketed in Belgium. International Journal of Food Microbiology, 150(1), 34-41. https://doi.org/10.1016/ j.ijfoodmicro.2011.07.013

Sandra, A., Afsah-Hejri, L., Tunung, R., Tuan Zainazor, T.C., Tang, J.Y.H., Ghazali, F.M., Nakaguchi, Y., Nishibuchi, M. and Son, R. (2012). Bacillus cereus and Bacillus thuringiensis in ready-to-eat cooked rice in Malaysia. International Food Research Journal, 19(6), 829-836.

Sarrías, J.A., Valero, M. and Salmerón, M.C. (2002). Enumeration, isolation and characterisation of Bacillus cereus strains from Spanish raw rice. Food Microbiology, 19(6), 589-595. https:// doi.org/10.1006/fmic.2002.0514

Schlegelova, J., Brychta, J., Klimova, E., Napravkinova, E. and Babak, V. (2003). The prevalence of and resistance to antimicrobial agents of Bacillus cereus isolates from foodstuffs. Veterinary Medicine-Czech, 48, 331-338. https://doi.org/10.17221/5787VETMED

Schmid, D., Rademacher. C., Kanitz, E.E., Frenzel, E., Simons, E., Allerberger F. and Ehling-Schulz, M. (2016). Elucidation of enterotoxigenic Bacillus cereus outbreaks in Austria by complementary epidemiological and microbiological investigations. International Journal of Food Microbiology, 232, 80 $-86$.

j.ijfoodmicro.2016.05.011

Schraft, H. and Griffith, W. (1995). Specific Oligonucleotide Primers for Detection of Lecithinase -Positive Bacillus spp. by PCR. Applied and Environmental Microbiology, 61, 98-102. https:// doi.org/10.1128/AEM.61.1.98-102.1995

Tallent, S.M., Rhodehamel, E.J., Harmon, S.M. and Bennett, R.W. (2012). BAM: Bacillus cereus. Retrieved April 15, 2013 from FDA website: http:// www.fda.gov/Food/FoodScienceResearch/ LaboratoryMethods/ucm070875.htm.

Tiwari, P.K. and Asgar, S. (2017). Diversification in
Flavoured Milk: A Review. International Journal of Clinical and Biomedical Research, 3(2), 15-20.

Tortora, G.J., Funke, B.R. and Case, C.L. (Eds.) (2016).

The Control of Microbial Growth. In Microbiology an Introduction. $9^{\text {th }}$ ed., p. 187-213. California, USA: Pearson Benjamin Cummings, San Francisco.

Tunung, R., Margaret, S.P., Jeyaletchumi, P., Chai, L.C., Tuan Zainazor, T.C., Ghazali, F.M., Nakaguchi, Y., Nishibuchi, M. and Son, R. (2010). Prevalence and Quantification of Vibrio parahaemolyticus in Raw Salad Vegetables at Retail Level. Journal of Microbiology and Biotechnology, 20, 391-396. https://doi.org/10.4014/jmb.0908.08009

Vidal-Martins, A.M.C., Rossi Jr., O.D. and RezendeLago, N.C. (2005). Mesophilic heterotrophic microorganisms and spore forming bacteria from Bacillus cereus group in ultra-high temperature milk. Arquivos Brasileiros de Medicina Veterinária e Zootecnia, 3, 396-400. https://doi.org/10.1590/S0102 $-09352005000300019$

Vyletělová, M., Švec, P., Páčová, Z., Sedláček, P. and Roubal, P. (2002). Occurrence of Bacillus cereus and Bacillus licheniformis strains in the course of UHT milk production. Czech Journal of Animal Science, 47(5), 200-205.

Witthuhn, M., Hinrichs, J. and Atamer, Z. (2011). Emerging challenges and trends in UHT processing of milk and other dairy products. Retrieved on January 7, 2019 from Food Magazine website: https://www.newfoodmagazine.com/article/5431/ emerging-challenges-and-trends-in-uht-processingof-milk-and-other-dairy-products/.

Wu, X.Y., Walker, M.J., Hornitzky, M. and Chin, J. (2005). Development of a group specific PCR combined with ARDRA for the identification of Bacillus species of environmental significance. Journal of Microbiological Methods, 64(1), 107-119. https://doi.org/10.1016/j.mimet.2005.04.021

Yusof, Y.M. (2011). Susu Coklat ada Bakteria. Retrieved on February 1, 2019 from myMetro website: http:// cintaiindah.blogspot.my/2011/07/adakah-undang2kita-gubal-lebih-baik.htmL.

Zhou, G., Liu, H., He, J., Yuan, Y. and Yuan, Z. (2008). The occurrence of Bacillus cereus, B. thuringiensis and $B$. mycoides in Chinese pasteurised full fat milk. International Journal of Food Microbiology, 121(2), 195-200. https://doi.org/10.1016/ j.ijfoodmicro.2007.11.028 